\title{
FAKTOR-FAKTOR PENYEBAB DAN DAMPAK KONVERSI LAHAN PERTANIAN
}

\author{
Oleh: Ita Rustiati Ridwan*)
}

\begin{abstract}
Abstrak
Semakin meningkatnya jumlah penduduk berarti jumlah kebutuhan menjadi lebih besar, salah satunya kebutuhan pada lahan. Mengingat sebagian besar penduduk Indonesia bermatapencaharian dalam bidang pertanian, maka semakin sempitlah lahan garapan karena telah dikonversi menjadi lahan permukiman, jalan, industri dan lainnya.

Konversi lahan pada dasarnya merupakan hal yang wajar terjadi, namun pada kenyataannya konversi lahan menjadi masalah karena terjadi di atas lahan pertanian yang masih produktif dan ketersediannya yang terbatas. Proses terjadinya alih fungsi lahan pertanian ke penggunaan non pertanian disebabkan oleh beberapa faktor meliputi faktor eksternal (adanya dinamika pertumbuhan perkotaan, demografi maupun ekonomi), faktor internal (kondisi sosial-ekonomi rumah tangga pertanian pengguna lahan), dan faktor kebijakan (aspek regulasi yang dikeluarkan pemerintah pusat maupun daerah yang berkaitan dengan perubahan fungsi lahan pertanian).

Dampak konversi lahan sawah antara lain menurunkan produksi padi nasional, kerugian akibat investasi dana untuk mencetak sawah, membangun waduk dan sistem irigasi. Dampak lainnya adalah menurunnya kesempatan kerja dalam bidang pertanian dan degradasi lingkungan. Upaya pencegahan konversi lahan sawah yang dapat dilakukan hanya bersifat pengendalian yang bertitik tolak dari faktor-faktor penyebab terjadinya konversi lahan sawah, yaitu faktor ekonomi, sosial, dan perangkat hukum. Selain itu, hendaknya didukung oleh keakuratan pemetaan dan pendataan penggunaan lahan yang dilengkapi dengan teknologi yang memadai.
\end{abstract}

Kata kunci: konversi lahan pertanian, faktor eksternal, faktor internal.

*) Dra. Ita Rustiati Ridwan, adalah Dosen PGSD UPI-Serang Banten.

\section{Pendahuluan}

Indonesia merupakan negara agraris dimana sebagian besar penduduk menggantungkan penghidupannya pada hasil pertanian. Fenomena lain juga menunjukkan, bahwa jumlah penduduk Indonesia setiap tahunnya terus meningkat. Tahun 2009 jumlah penduduk mencapai 230 juta dengan laju pertumbuhan 1,33\% (Data BPS, 2009). Semakin meningkatnya jumlah penduduk berarti jumlah kebutuhan menjadi lebih besar, salah satunya kebutuhan pada lahan. 
Apabila kita kaitkan antara dua fenomena tersebut, yaitu sebagian besar penduduk Indonesia adalah petani sedangkan jumlah penduduk terus meningkat cepat, maka akan berdampak terhadap semakin sempitnya lahan pertanian. Sampai saat ini, teori produktivitas hasil pertanian masih dipengaruhi oleh luasnya lahan garapan. Dengan demikian, jumlah kepemilikan lahan oleh petani sangat sempit. Hal ini akan berdampak terhadap besarnya jumlah pendapatan yang akan diterima oleh setiap rumah tangga tani.

Utomo (1992) menyatakan bahwa lahan sebagai modal alami yang melandasi kegiatan kehidupan dan penghidupan, memiliki dua fungsi dasar, yakni:

1) Fungsi kegiatan budaya; suatu kawasan yang dapat dimanfaatkan untuk berbagai penggunaan, seperti pemukiman, baik sebagai kawasan perkotaan maupun pedesaan, perkebunan hutan produksi dan lain-lain.

2) Fungsi lindung; kawasan yang ditetapkan dengan fungsi utamanya untuk melindungi kelestarian lingkungan hidup yang ada, yang mencakup sumberdaya alam, sumberdaya buatan, dan nilai sejarah serta budaya bangsa yang bisa menunjang pemanfaatan budidaya.

Sehubungan dengan fungsi lahan dalam kegiatan budaya, maka keberadaannya menjadi sangat penting apabila dikaitkan dengan sebagian besar mata pencaharian bangsa Indonesia yaitu bertani. Keterikatan sektor pertanian terhadap luas lahan masih sangat tinggi. Walau demikian berdasarkan status kepemilikannya, Sihaloho (2004) membedakan penggunaan tanah ke dalam tiga kategori, yaitu:

1) Masyarakat yang memiliki tanah luas dan menggarapkan tanahnya kepada orang lain; pemilik tanah menerapkan sistem sewa atau bagi hasil.

2) Pemilik tanah sempit yang melakukan pekerjaan usaha tani dengan tenaga kerja keluarga, sehingga tidak memanfaatkan tenaga kerja buruh tani.

3) Pemilik tanah yang melakukan usaha tani sendiri tetapi banyak memanfaatkan tenaga kerja buruh tani, baik petani bertanah sempit maupun bertanah luas.

Konversi lahan pertanian ke non-pertanian telah menjadi permasalahan, baik secara ekonomi maupun masalah lingkungan di negara ini. Penyebabnya, selain pertambahan penduduk yang dijelaskan di atas juga aktivitas pembangunan yang terjadi pada berbagai bidang. Sehingga permintaan akan lahan terus bertambah, sedangkan jumlah ketersediaannya terbatas.

Konversi lahan adalah perubahan fungsi sebagian atau seluruh kawasan lahan dari fungsinya semula (seperti yang direncanakan) menjadi fungsi lain yang membawa dampak negatif (masalah) terhadap lingkungan dan potensi lahan itu sendiri (Utomo dkk, 1992). Konversi lahan merupakan konsekuensi logis dari peningkatan aktivitas dan jumlah penduduk serta proses pembangunan lainnya. Konversi lahan pada dasarnya merupakan hal yang wajar terjadi, namun pada kenyataannya konversi lahan menjadi masalah karena terjadi di atas lahan pertanian yang masih produktif.

Berdasarkan permasalahan di atas, tujuan tulisan ini untuk: (1) mengidentifikasi faktor-faktor yang menentukan terjadinya konversi lahan; dan (2) 
memperkirakan dampak konversi terhadap perekonomian, khususnya penurunan produksi padi.

\section{Konversi Lahan}

Utomo dkk (1992) mendefinisikan alih fungsi lahan atau lazimnya disebut sebagai konversi lahan adalah perubahan fungsi sebagian atau seluruh kawasan lahan dari fungsinya semula (seperti yang direncanakan) menjadi fungsi lain yang menjadi dampak negatif (masalah) terhadap lingkungan dan potensi lahan itu sendiri. Alih fungsi lahan dalam artian perubahan/penyesuaian peruntukan penggunaan, disebabkan oleh faktor-faktor yang secara garis besar meliputi keperluan untuk memenuhi kebutuhan penduduk yang makin bertambah jumlahnya dan meningkatnya tuntutan akan mutu kehidupan yang lebih baik. antara lain:

Sihaloho (2004) membagi konversi lahan kedalam tujuh pola atau tipologi,

1) Konversi gradual berpola sporadis; dipengaruhi oleh dua faktor utama yaitu lahan yang kurang/tidak produktif dan keterdesakan ekonomi pelaku konversi.

2) Konversi sistematik berpola 'enclave'; dikarenakan lahan kurang produktif, sehingga konversi dilakukan secara serempak untuk meningkatkan nilai tambah.

3) Konversi lahan sebagai respon atas pertumbuhan penduduk (population growth driven land conversion); lebih lanjut disebut konversi adaptasi demografi, dimana dengan meningkatnya pertumbuhan penduduk, lahan terkonversi untuk memenuhi kebutuhan tempat tinggal.

4) Konversi yang disebabkan oleh masalah sosial (social problem driven land conversion); disebabkan oleh dua faktor yakni keterdesakan ekonomi dan perubahan kesejahteraan.

5) Konversi tanpa beban; dipengaruhi oleh faktor keinginan untuk mengubah hidup yang lebih baik dari keadaan saat ini dan ingin keluar dari kampung.

6) Konversi adaptasi agraris; disebabkan karena keterdesakan ekonomi dan keinginan untuk berubah dari masyarakat dengan tujuan meningkatkan hasil pertanian.

7) Konversi multi bentuk atau tanpa bentuk; konversi dipengaruhi oleh berbagai faktor, khususnya faktor peruntukan untuk perkantoran, sekolah, koperasi, perdagangan, termasuk sistem waris yang tidak dijelaskan dalam konversi demografi.

Sumaryanto (1994) dalam Furi (2007) memaparkan bahwa jika suatu lokasi terjadi konversi lahan pertanian, segera lahan-lahan di sekitarnya akan terkonversi dan sifatnya cenderung progresif.

Irawan (2005) dalam Akbar (2008) mengemukakan bahwa konversi tanah lebih besar terjadi pada tanah sawah dibandingkan dengan tanah kering karena dipengaruhi oleh tiga faktor, yaitu pertama, pembangunan kegiatan non pertanian seperti kompleks perumahan, pertokoan, perkantoran, dan kawasan industri lebih mudah dilakukan pada tanah sawah yang lebih datar dibandingkan dengan tanah kering. Kedua, akibat pembangunan masa lalu yang terfokus pada upaya peningkatan produk padi maka infrastruktur ekonomi lebih tersedia di daerah 
persawahan daripada daerah tanah kering. Ketiga, daerah persawahan secara umum lebih mendekati daerah konsumen atau daerah perkotaan yang relatif padat penduduk dibandingkan daerah tanah kering yang sebagian besar terdapat di wilayah perbukitan dan pegunungan.

Konversi lahan biasanya terkait dengan proses perkembangan wilayah, bahkan dapat dikatakan bahwa konversi lahan merupakan konsekuensi dari perkembangan wilayah. Sebagian besar konversi lahan yang terjadi, menunjukkan adanya ketimpangan dalam penguasaan lahan yang lebih didominasi oleh pihak kapitalis dengan mengantongi izin mendirikan bangunan yang dikeluarkan oleh pemerintah

\section{Perkembangan Konversi Lahan Sawah}

Perkembangan konversi lahan dapat dikelompokkan menjadi dua. Pertama, perkembangan konversi lahan menurut wilayah administratif, dalam hal ini pulau. Kedua, perkembangan konversi lahan menurut jenis irigasi, dalam hal ini irigasi teknis, irigasi setengah teknis, irigasi sederhana, dan tadah hujan.

Konversi lahan sawah didefinisikan sebagai konversi lahan neto. Artinya luas lahan tahun $t(L t)$ adalah luas lahan tahun sebelumnya ( $L t-1)$ ditambah pencetakan sawah baru $(C t)$ dikurangi alih fungsi lahan sawah $(A t)$. Secara matematika, diformulasikan sebagai berikut:

$(C t-A t)=L t-L t-1$

Sumber: Irawan, 2000.

Dengan demikian jika konversi lahan sawah bernilai positif, berarti hanya terjadi pencetakan sawah baru, atau pencetakan lahan sawah yang terjadi lebih luas dari alih fungsi lahan sawah masing-masing pada tahun $t$. Sebaliknya jika konversi lahan sawah bernilai negatif, berarti hanya terjadi alih fungsi lahan sawah atau, alih fungsi lahan sawah lebih luas dari pencetakan sawah masing-masing pada tahun $t$.

\section{Faktor Penyebab}

Proses terjadinya alih fungsi lahan pertanian ke penggunaan non pertanian disebabkan oleh beberapa faktor. Kustiwan (1997) dalam Supriyadi (2004) menyatakan bahwa setidaknya ada tiga faktor penting yang menyebabkan terjadinya alih fungsi lahan sawah yaitu:

1) Faktor Eksternal, disebabkan oleh adanya dinamika pertumbuhan perkotaan (fisik maupun spasial), demografi maupun ekonomi.

2) Faktor Internal, disebabkan oleh kondisi sosial-ekonomi rumah tangga pertanian pengguna lahan.

3) Faktor Kebijakan, disebabkan oleh aspek regulasi yang dikeluarkan pemerintah pusat maupun daerah yang berkaitan dengan perubahan fungsi lahan pertanian.

Pasandaran (2006) menjelaskan paling tidak ada tiga faktor, baik sendirisendiri maupun bersama-sama yang merupakan determinan konversi lahan sawah, yaitu: 
1) Kelangkaan sumberdaya lahan dan air

2) Dinamika pembangunan

3) Peningkatan jumlah penduduk

Adapun faktor-faktor yang mempengaruhi konversi lahan sawah di tingkat petani menurut Rusastra (1994) dalam Munir (2008) adalah sebagai pilihan alokasi sumber daya melalui transaksi yang dipengaruhi oleh kondisi sosial ekonomi petani seperti tingkat pendidikan, pendapatan dan kemampuan ekonomi secara keseluruhan serta pajak tanah, harga tanah dan lokasi tanah. Sehingga diperlukan kontrol agar sesuai dengan Rencana Tata Ruang. Berikut uraian beberapa faktor penyebab konversi lahan yang diambil secara umum dari beberapa kasus.

\section{a. Faktor Ekonomi}

Secara ekonomi alih fungsi lahan yang dilakukan petani baik melalui transaksi penjualan ke pihak lain ataupun mengganti pada usaha non padi merupakan keputusan yang rasional. Sebab dengan keputusan tersebut petani berekspektasi pendapatan totalnya, baik dalam jangka pendek maupun dalam jangka panjang akan meningkat. Penelitian yang dilakukan oleh beberapa peneliti, menunjukkan bahwa penggunaan lahan sawah untuk penanaman padi sangat inferior dibanding penggunaan untuk turisme, perumahan dan industri.

Penelitian Syafa'at (2001) mengemukakan bahwa pada sentra produksi padi utama di Jawa dan Luar Jawa, menunjukkan bahwa selain faktor teknis dan kelembagaan, faktor ekonomi yang menetukan alih fungsi lahan sawah ke pertanian dan non pertanian adalah : (1) nilai kompetitif padi terhadap komoditas lain menurun; (2) respon petani terhadap dinamika pasar, lingkungan, dan daya saing usahatani meningkat.

Konversi lahan sawah ke pertanian lain dan ke pemukiman dapat terjadi tanpa melalui transaksi. Namun kasus di Jawa menunjukkan bahwa kasus konversi seperti itu jauh lebih sedikit dibandingkan yang melalui transaksi. Ini menunjukkan bahwa harga lahan sawah sangat mempengaruhi konversi lahan sawah (Sumaryanto, Hermanto, dan Pasandaran 1996). Alasan utama petani melakukan konversi lahan adalah karena kebutuhan dan harga lahan yang tinggi dan skala usaha yang kurang efisien untuk diusahakan. Dengan demikian, alasan utama petani melakukan konversi lahan adalah karena kebutuhan, lahannya berada dalam kawasan industri, serta harga lahan. Sehingga pajak lahan yang tinggi cenderung mendorong petani untuk melakukan konversi.

Penelitian Jamal (2001), di Kabupaten Karawang, Jawa Barat, harga jual lahan yang diterima petani dalam proses alih fungsi lahan secara signifikan dipengaruhi oleh status lahan, jumlah tenaga kerja yang terserap di lahan tersebut, jarak dari saluran tersier, jarak dari jalan, dan jarak dari kawasan industri atau pemukiman.

Secara makro aktivitas ekonomi membutuhkan input lahan, diantaranya lahan sawah, untuk aktivitas ekonomi di Indonesia. Namun untuk Luar Jawa ketersediaan dana pemerintah mencetak sawah baru dapat mengimbangi laju konversi menjadi positif. Keterbatasan dana pada saat krisis ekonomi menyebabkan 
faktor-faktor yang mendorong konversi semakin besar, sedangkan dana untuk pencetakan sawah baru jauh berkurang, sehingga konversi lahan sawah menjadi jauh meningkat. Secara makro hubungan konversi lahan sawah dengan peningkatan jumlah penduduk tidak berkorelasi positif.

Temuan yang menarik adalah bahwa rataan konversi lahan sawah berhubungan negatif dengan pertumbuhan nilai tukar petani. Hasil ini sama dengan hasil penelitian-penelitian di lingkup mikro sebelumnya. Dimana usaha berproduksi padi di lahan sawah sudah tidak memberikan insentif bagi petani. Daya saing produk pertanian, khususnya padi, dan harga lahan yang cenderung terus meningkat mendorong petani untuk menjual lahan sawahnya untuk beralih ke usaha lain.

\section{b. Faktor Sosial}

Menurut Witjaksono (1996) ada lima faktor sosial yang mempengaruhi alih fungsi lahan, yaitu: perubahan perilaku, hubungan pemilik dengan lahan, pemecahan lahan, pengambilan keputusan, dan apresiasi pemerintah terhadap aspirasi masyarakat. Dua faktor terakhir berhubungan dengan sistem pemerintahan. Dengan asumsi pemerintah sebagai pengayom dan abdi masyarakat, seharusnya dapat bertindak sebagai pengendali terjadinya alih fungsi lahan. Oleh karena itu kedua faktor itu tidak diuraikan lebih lanjut dalam tulisan ini.

Sistem transportasi dan komunikasi yang memadai telah membuka wawasan penduduk pedesaan terhadap dunia luar. Bahkan muncul persepsi, terutama generasi mudanya, terhadap profesi petani tidak jauh berbeda dengan persepsi masyarakat perkotaan, yaitu bahwa profesi petani adalah pekerjaan yang kotor, sengsara, dan kurang bergengsi. Akibat perubahan cara pandang tersebut, citra petani dibenak mereka semakin menurun. Dengan demikian lahan pertanian bukan lagi merupakan aset sosial semata, tetapi lebih diandalkan sebagai aset ekonomi atau modal kerja bila mereka beralih profesi di luar bidang pertanian. Mereka tidak akan keberatan melepaskan lahan pertaniannya untuk dialihfungsikan pada penggunaan non pertanian. Keadaan tersebut semakin diperburuk dengan kondisi ekonomi seperti saat ini, dimana kesempatan kerja formal semakin kecil. Tidak sedikit petani menjual lahannya untuk biaya masuk kerja pada lapangan kerja formal, atau membeli kendaraan untuk angkutan umum.

Bagi petani yang hanya menggantungkan kehidupan dan penghidupannya pada usahatani akan sulit dipisahkan dari lahan pertanian yang dikuasainya. Mereka tidak berani menanggung risiko atas ketidakpastian penghidupannya sesudah lahan pertaniannya dilepaskan kepada orang lain. Di samping itu, status sosial penduduk pedesaan masih ada yang dikaitkan dengan luas kepemilikan lahannya. Dengan memiliki lahan yang luas, petani dapat memberi pekerjaan kepada tetangganya. Hubungan antara pemilik lahan dengan buruhnya diikat dalam ikatan kekeluargaan yang saling membutuhkan, meskipun dalam status yang berbeda. Dalam hal ini, lahan pertanian merupakan aset sosial bagi pemiliknya yang dapat digunakan sebagai instrumen untuk mempertahankan kehormatan 
keluarganya. Lahan pertanian yang memiliki fungsi sosial seperti ini tidak mudah tergantikan dengan imbalan ganti rugi berupa uang meskipun jumlahnya memadai.

Faktor sosial lainnya adalah adanya sistem waris. Sistem waris dapat menyebabkan kepemilikan lahan yang semakin menyempit. Lahan pertanian yang sempit di samping pengelolaannya kurang efisien juga hanya memberikan sedikit kontribusi bagi pendapatan keluarga petani pemiliknya. Biasanya petani tidak lagi mengandalkan penghidupannya dari bidang pertanian, sehingga mereka beralih mencari sumber pendapatan baru di bidang non pertanian. Untuk itu mereka membutuhkan modal atau dana yang diperoleh dengan cara menjual lahan pertaniannya. Banyak juga lahan yang diwariskan petani kepada anaknya digunakan untuk pemukiman sebagai akibat pengembangan keluarga melalui perkawinan.

Bentuk lain yang berhubungan dengan pemecahan lahan adalah lembaga perkawinan yang umumnya berlaku di lingkungan masyarakat petani di pedesaan. Terbentuknya keluarga baru biasanya dibekali sebidang lahan oleh masing-masing pihak orangtua suami dan isteri untuk digabungkan menjadi milik bersama. Permasalahannya letak kedua lahan tersebut cenderung terpisah., sehingga kurang efisien dalam pengelolaannya dan sulit mengendalikannya. Dua kondisi ini mendorong pemiliknya untuk menjual sebagian lahan tersebut.

\section{Dampak Konversi dan Upaya Pengendaliannya}

a. Dampak Konversi Lahan Sawah

Dampak konversi lahan sawah dapat dipandang dari dua sisi. Pertama, dari fungsinya, lahan sawah diperuntukan untuk memproduksi padi. Dengan demikian adanya konversi lahan sawah ke fungsi lain akan menurunkan produksi padi nasional. Kedua, dari bentuknya perubahan lahan sawah ke pemukiman, perkantoran, prasarana jalan dan lainnya berimplikasi besarnya kerugian akibat sudah diinvestasikannya dana untuk mencetak sawah, membangun waduk dan sistem irigasi. Volume produksi yang hilang akibat konversi lahan sawah ditentukan oleh: pola tanam yang diterapkan di lahan sawah yang belum dikonversi; produktivitas usahatani dari masing-masing komoditi dari pola tanam yang diterapkan; dan luas lahan sawah yang terkonversi.

Irawan dan Friyatno (2002) dalam penelitiannya mengatakan, dampak konversi lahan sawah terhadap produksi padi di Jawa selama 18 tahun (1981-1999) diperkirakan secara akumulasi mencapai 50,9 juta ton atau sekitar 2,82 juta ton per tahun. Kehilangan tersebut tidak mampu ditutup oleh pencetakan lahan sawah yang dilakukan di luar Jawa. Karena kehilangan produksi padi dari areal lahan sawah di Jawa tersebut setara dengan 1,7 juta ton beras per tahun yang jumlahnya sebanding dengan impor beras Indonesia pada periode 1984 - 1997 yang berkisar antara 1,5 2,5 juta ton beras per tahun. Ketidakmampuan sawah baru menggantikan sawah yang terkonversi di Jawa disebabkan rata-rata sawah di Jawa tingkat produktivitasnya lebih tinggi dibandingkan produktivitas lahan sawah di Luar Jawa, apalagi sawah-sawah yang baru dicetak. 
Namun demikian jika tidak ada upaya pencetakan lahan sawah di Luar Jawa tentunya impor yang dibutuhkan akan lebih besar lagi. Di samping itu hendaknya perbaikan teknologi budidaya padi lahan sawah dan lahan kering serta upaya-upaya penyuluhan yang akhir-akhir ini menurun, sebaiknya ditingkatkan lagi secara terus menerus. Di sisi permintaan, upaya diversifikasi pangan pokok dengan bahan lokal yang masih tersendat perlu diupayakan terus. Jika dikaji secara fisik, menurut Nasoetion dan Winoto (1996) alih fungsi lahan sawah ke non pertanian merupakan suatu proses yang mahal. Biaya investasi untuk pencetakan dan pengembangan sistem pertanian sawah sangat besar, baik kaitannya dengan pembangunan waduk, sistem irigasi, maupun pemantapan ekosistem sawah yang umumnya butuh waktu lebih dari 10 tahun. Sumaryanto, Hermanto, dan Pasandaran, (1996) memperkirakan investasi membangun lahan sawah irigasi membutuhkan biaya sekitar Rp 4,9 juta/ha pada tahun 1989. Dengan menggunakan perkiraan tersebut pada nilai kini maka kerugian akibat investasi lahan sawah yang hilang disebabkan adanya konversi lahan sawah cukup besar.

Dampak lain dari alih fungsi lahan pertanian adalah: kesempatan kerja pertanian menurun sejalan dengan menurunnya lahan pertanian yang tersedia, kesempatan kerja yang terkait secara langsung maupun tidak langsung dengan kegiatan produksi padi, dan degradasi lingkungan (Sumaryanto, Hermanto, dan Pasandaran, 1996). Di samping itu biaya investasi pengembangan struktur sosial terutama dalam bentuk pengembangan sistem kelembagaan pertanian, yang menjadi soko guru sistem produksi beras di Indonesia sangat mahal (Nasoetion dan Winoto, 1996).

\section{b. Upaya Pengendalian Konversi Lahan Sawah}

Berdasarkan fakta, upaya pencegahan konversi lahan sawah sulit dilakukan, karena lahan sawah merupakan private good yang legal untuk ditransaksikan. Karena itu, upaya yang dapat dilakukan hanya bersifat pengendalian. Pengendalian yang dilakukan sebaiknya bertitik tolak dari faktor-faktor penyebab terjadinya konversi lahan sawah, yaitu faktor ekonomi, sosial, dan perangkat hukum. Namun hal tersebut hendaknya didukung oleh keakuratan pemetaan dan pendataan penggunaan lahan yang dilengkapi dengan teknologi yang memadai (Suwarno, 1996).

Data menunjukkan konversi lahan sawah terus terjadi. Menurut Jamal (2000) permasalahan konversi lahan sawah ke penggunaan non pertanian dan terjadi akumulasi penguasaan lahan pada pihak tertentu dapat dijawab dengan reformasi agraria. Namun kegiatan ini membutuhkan tenaga pelaksana yang jujur, tersedianya data penguasaan dan pemilikan lahan yang lengkap, dan dukungan dana yang terus menerus. Prasyarat tersebut menyebabkan banyak negara gagal melaksanakannya. Dari faktor sosial, perilaku dan norma-norma yang berlaku di masyarakat cenderung mendorong terjadinya konversi lahan. Lahan sebagai private goods berbeda dengan common goods yang dapat dikendalikan pemanfaatannya berdasarkan kesepakatan sosial, seperti layaknya pada kawasan hutan dan perairan masih dapat dilindungi pemanfaatannya dengan kesepakatan masyarakat setempat. 
Dari tiga faktor diatas, faktor ekonomi dan perangkat hukum secara simultan diharapkan dapat mengendalikan konversi lahan sawah. Dana yang diperoleh dari penerimaan pajak progresif tersebut digunakan untuk pencetakan sawah baru dan perbaikan irigasi. Sejalan dengan upaya peningkatan keakuratan data dan perangkat hukum yang tegas, upaya yang realistis untuk dilakukan adalah mencetak sawah baru dan meningkatkan kualitas irigasi.

\section{Penutup}

Konversi lahan sawah di Jawa jauh lebih besar dibandingkan wilayah lain di Indonesia, dan kecenderungannya terus meningkat. Kondisi ini mengindikasikan upaya pengendalian konversi lahan sawah yang dilakukan pemerintah tidak efektif. Di luar Jawa konversi lahan sawah bersifat fluktuatif. Hal ini disebabkan adanya upaya pemerintah mencetak sawah baru untuk mengantisipasi tingginya konversi yang terjadi di Jawa.

Tekanan ekonomi pada saat krisis ekonomi menyebabkan banyak petani menjual asetnya berupa sawah untuk memenuhi kebutuhan hidup. Dampaknya secara umum meningkatkan konversi lahan sawah dan makin meningkatkan penguasaan lahan pada pihak-pihak pemilik modal.

Tingginya konversi lahan sawah di Jawa makin menguatkan indikasi bahwa peraturan pengendalian konversi lahan sawah yang ada tidak efektif. Beberapa penelitian lingkup mikro menunjukkan bahwa harga lahan, aktivitas ekonomi suatu wilayah, pengembangan pemukiman, dan daya saing produk pertanian merupakan faktor-faktor ekonomi yang menentukan konversi lahan sawah. Sementara itu dalam lingkup makro: konversi lahan sawah berkorelasi positif dengan pertumbuhan PDB/PDB; konversi lahan sawah berkorelasi negatip dengan nilai tukar petani. Kedua hal ini sejalan dengan temuan pada lingkup mikro.

Secara mikro, berkembangnya pemukiman mempengaruhi konversi lahan sawah, namun secara makro pengembangan pemukiman akibat peningkatan jumlah penduduk tidak menunjukkan hubungan yang positif. Hal ini mengindikasikan adanya trend pemilikan rumah bukan hanya sebagai tempat tinggal tetapi sebagai investasi.

Faktor sosial yang berlaku di masyarakat kecenderungannya justru memicu terjadinya konversi lahan sawah. Sementara itu perangkat peraturan pertanahan yang berlaku belum mampu mengendalikan laju konversi lahan sawah. Kerugian ekonomi akibat adanya konversi lahan sawah, berupa hilangnya produksi padi, tidak berfungsinya sistem irigasi, dan tidak berfungsinya kelembagaan pertanian. Jika diperkirakan secara ekonomi nilai kerugian itu sangat besar. Bahkan upaya pencetakan sawah baru belum mampu menutupi kehilangan pruduksi, sehingga Indonesia harus mengimpor beras.

Upaya pencegahan konversi lahan sawah sulit dilakukan, upaya yang dapat dilakukan hanya bersifat pengendalian. Prasyarat yang diperlukan untuk itu adalah perangkat peraturan yang tegas dan harus didukung oleh keakuratan pemetaan dan pendataan penggunaan lahan yang dilengkapi dengan teknologi yang memadai. Dengan pendataan yang akurat dan penegakan hukum yang konsisten, pengenaan 
pajak progresif pada pembelian lahan sawah lebih aplikatif. Dana penerimaan pajak tersebut digunakan untuk pencetakan sawah baru dan perbaikan irigasi.

\section{Daftar Pustaka}

Akbar, Rizky Ali. 2008. Proses Pembebasan Tanah Pertanian Untuk Pembangunan Kawasan Perumahan. [Skripsi] Fakultas Pertanian. Bogor: Institut Pertanian Bogor.

Ariani, M. 2003. Dinamika Konsumsi Beras Rumah Tangga dan Kaitannya dengan Diversifikasi Konsumsi Pangan. Makalah disampaikan pada Seminar Nasional "Peluang Indonesia untuk Mencukupi Kebutuhan Beras" tanggal 2 Oktober 2003 di Bogor. Pusat Penelitian dan Pengembangan Sosial Ekonomi Pertanian, Badan Litbang Departemen Pertaniab, Bogor.

Irawan, B., A. Purwoto, C. Saleh, A. Supriatna, dan N.A. Kirom. 2000. Pengembangan Model Kelembagaan Reservasi Lahan Pertanian. Laporan Hasil Penelitian. Pusat Penelitian Sosial Ekonomi Pertanian Badan Penelitian dan Pengembangan Pertanian Departemen Pertanian. Bogor.

Irawan, B. dan S. Friyatno. 2002. Dampak Konversi Lahan Sawah di Jawa Terhadap Produksi Beras dan Kebijakan Pengendaliannya. Jurnal SosialEkonomi Pertanian dan Agribisnis SOCA: Vol.2 No.2 : 79 - 95. Fakultas Pertanian Universitas Udayana. Denpasar.

Jamal, E. 2001. Faktor-Faktor yang Mempengaruhi Pembentukan Harga Lahan Sawah pada Proses Alih Fungsi Lahan ke Penggunaan Non Pertanian: Studi Kasus di Beberapa Desa, Kabupaten Karawang, Jawa Barat. Jurnal Agro Ekonomi, Volume 19 Nomor 1:45-63. Pusat Penelitian dan Pengembangan Sosial Ekonomi Pertanian, Badan Penelitian dan Pengembangan Pertanian, Departemen Pertanian. Bogor. 2000. Beberapa Permasalahan dalam Pelaksanaan Reformasi Agraria di Indonesia. Forum Agro Ekonomi. Volume 18. No. 1 dan 2.: 16 - 24. Pusat Penelitian Sosial Ekonomi Pertanian, Badan Penelitian dan Pengembangan Pertanian, Departemen Pertanian. Bogor.

Kurniawati, Yoyoh. 2005. Analisis Perubahan Penggunaan Lahan Pertanian ke Non Pertanian dan Pengaruhnya Terhadap Daya Dukung Lahan di Kecamatan Lembang Kabupaten Bandung. [Tesis] Sekolah Pascasarjana. Bogor: Institut Pertanian Bogor.

Munir, Misbahul. 2008. Hubungan Antara Konversi Lahan Pertanian dengan Tingkat Kesejahteraan Rumah Tangga Petani. [Skripsi] Fakultas Pertanian. Bogor: Institut Pertanian Bogor.

Nasoetion, L. dan J. Winoto. 1996. Masalah Alih Fungsi Lahan Pertanian dan Dampaknya terhadap Keberlangsungan Swasembada Pangan. Dalam Prosiding Lokakarya " Persaingan Dalam Pemanfaatan Sumberdaya Lahan dan Air”: Dampaknya terhadap Keberlanjutan Swasembada Beras: 64 - 82. Hasil Kerja sama Pusat Penelitian Sosial Ekonomi Pertanian dengan Ford Foundation.Bogor. 
Pasandaran, Effendi. 2006. Alternatif Kebijakan Pengendalian Konversi Lahan Sawah Beririgasi di Indonesia dalam Jurnal Litbang Pertanian 25(4) 2006.

Putri, Rubyani.I. 2008. Konversi Lahan dan Dampak yang Ditimbulkan Terhadap Tata Guna Lahan Perkotaan. [Skripsi] Fakultas Pertanian. Bogor: Institut Pertanian Bogor.

Rusastra, I W. dan G.S. Budhi. 1997. Konversi Lahan Pertanian dan Strategi Antisipatif dalam Penanggulangannya. Julnal Penelitian dan Pengembangan Pertanian. Volume XVI, Nomor 4:107 - 113. Badan Penelitian dan Pengembangan Pertanian, Departemen Pertanian. Bogor.

Rusatra, I.W., G.S. Budhi, S. Bahri, K.M. Noekman, M.S.M. Tambunan, Sunarsih dan T. Sudaryanto. 1997. Perubahan Struktur Ekonomi Pedesaan: Analisis SensusPertanian 1983 dan 1993. Laporan Hasil Penelitian. Pusat Penelitian Sosial Ekonomi Pertanian Badan Penelitian dan Pengembangan Pertanian Departemen Pertanian. Bogor.Pusat Penelitian Sosial Ekonomi Pertanian Badan Penelitian dan Pengembangan Pertanian Departemen Pertanian. Bogor.

Sihaloho, Martua. 2004. Konversi Lahan Pertanian dan Perubahan Struktur Agraria. [Tesis] Sekolah Pascasarjana. Bogor: Institut Pertanian Bogor.

Singarimbun, M dan Sofian Effendi. 1989. Metode Penelitian Survei. Jakarta: LP3ES.

Sitorus, MT. F. 2002: Lingkup Agraria dalam Menuju Keadilan Agraria :70 Tahun Gunawan Wiradi, Penyunting Endang, Suhendar et al. Yayasan AKATIGA, Bandung.

Supriyadi, Anton. 2004. Kebijakan Alih Fungsi Lahan dan Proses Konversi Lahan Pertanian. [Skripsi] Fakultas Pertanian. Bogor: Institut Pertanian Bogor.

Sumaryanto, Hermanto, dan E. Pasandaran. 1996. Dampak Alih Fungsi Lahan Sawah Terhadap Pelestarian Swasembada Beras dan Sosial Ekonomi Petani. Dalam Prosiding Lokakarya " Persaingan Dalam Pemanfaatan Sumberdaya Lahan dan Air": Dampaknya terhadap Keberlanjutan Swasembada Beras: 92 - 112. Hasil Kerja sama Pusat Penelitian Sosial Ekonomi Pertanian dengan Ford Foundation. Bogor.

Syafa'at, N., W. Sudana, N. Ilham, H. Supriyadi dan R. Hendayana. 2001. Kajian Penyebab Penurunan Produksi Padi Tahun 2001 di Indonesia. Laporan Hasil Penelitian: Analisis Kebijaksanaan Pembangunan Pertanian Respon terhadap Issu Aktual. Pusat Penelitian dan Pengembangan Sosial Ekonomi Pertanian, Badan Penelitian Pertanian, Departemen Pertanian. Bogor.

Syafa'at, N., H.P. Saliem dan Saktyanu, K.D. 1995. Faktor-Faktor yang Mempengaruhi Konversi Sawah di Tingkat Petani. Prosiding Pengembangan Hasil Penelitian "Profil Kelembagaan Pemanfaatan Sumberdaya Pertanian, dan Prospek Pengembangan Agribisnis di Indonesia. Buku 1: 42 - 56. Pusat Penelitian Sosial Ekonomi Pertanian, Badan Penelitian dan Pengembangan Pertanian, Departemen Pertanian. Bogor.

Syam, A., M. Syukur, N. Ilham dan Sumedi. 2000. Baseline Survey Program Pemberdayaan Petani Untuk Mencapai Ketahanan Pangan. Laporan 
Penelitian.Pusat Penelitian Sosial Ekonomi Pertanian, Badan Penelitian dan Pengembangan Pertanian, Departemen Pertanian. Bogor.

Suwarno, P.S. 1996. Alih Fungsi Tanah Pertanian dan Langkah-Langkah Penanggulangannya. Dalam Prosiding Lokakarya " Persaingan Dalam Pemanfaatan Sumberdaya Lahan dan Air": Dampaknya terhadap Keberlanjutan Swasembada Beras: 121 - 134. Hasil Kerja sama Pusat Penelitian Sosial Ekonomi Pertanian dengan Ford Foundation. Bogor.

Syaukat, Y. 2003. Ekonomi Sumberdaya \& Lingkungan Lanjutan: Ekonomi Sumberdaya Lahan. Bahan Kuliah. Program Studi Ilmu Ekonomi Pertanian Program Pascasarjana, Institut Pertanian Bogor. Bogor. 33 p.

Utomo, M., Eddy Rifai dan Abdulmutalib Thahir. 1992. Pembangunan dan Alih Fungsi Lahan. Lampung: Universitas Lampung.

Wiradi, Gunawan. 2000. Reforma Agraria: Perjalanan Yang Belum Berakhir.

Witjaksono, R. 1996. Alih Fungsi Lahan: Suatu Tinjauan Sosiologis. Dalam Prosiding Lokakarya "Persaingan Dalam Pemanfaatan Sumberdaya Lahan dan Air": Dampaknya terhadap Keberlanjutan Swasembada Beras: 113 120. Hasil Kerja sama Pusat Penelitian Sosial Ekonomi Pertanian dengan Ford Foundation. Bogor. Yogyakarta: Pustaka Belajar Offset. 